\begin{tabular}{lr}
\hline \multicolumn{1}{c}{ D Y N A M I C E C O N O M E T R I C } & M O D E L S \\
DOI: http://dx.doi.org/10.12775/DEM.2015.007 & Vol. 15 (2015) 111-128 \\
\hline Submitted October 23, 2015 & ISSN (online) 2450-7067 \\
Accepted December 15, 2015 & ISSN (print) 1234-3862
\end{tabular}

Sylwester Bejger*

\title{
Testing Parallel Pricing Behavior in the Polish Wholesale Fuel Market: an ARDL - Bound Testing Approach
}

\begin{abstract}
A b s t r a c t. In this study, we investigated whether the observed series of fuel prices can be compatible with a specific theoretical model of strategic player interaction. Our primary interest is in determining whether a parallel pricing policy, implied by a theoretical model of strategic interactions, can be an industry-observed pricing mechanism. Therefore, we first calculated various descriptive statistics of the price series to discover any common patterns of individual series. Next, we determined whether parallel co-movement of the price levels exist using an ARDL - bound testing approach. This study finds that if we restricted our research to the described pricing mechanism (IPP pricing based on previous day fundamentals), the players will have chosen the levels of price in a parallel mode; this excludes 2007, when LOTOS appeared to be the price leader.
\end{abstract}

$\mathrm{K}$ e y w o r d s: wholesale fuel market, parallel pricing, cointegration.

J E L Classification: L1, L7, C22.

\section{Introduction}

The general objective of this paper was to discover particular, strategic patterns in the price behavior of the players in the Polish wholesale fuel market in a sample period of 2004 to 2013. This study is shaped as an intersection of monitoring and verification (to use the terminology of Harrington, 2008) in the context of behavioral screening. However, this study is more broadly understood because we did not constitute tests for verification of the

\footnotetext{
${ }^{*}$ Correspondence to: Sylwester Bejger, Nicolaus Copernicus University, Department of Econometrics and Statistics, ul. Gagarina 13A, 87-100 Toruń, Poland, e-mail: sylw@umk.pl.

(C) 2015 Nicolaus Copernicus University. All rights reserved.

http://www.dem.umk.pl/dem
} 
hypothesis of collusion (tacit or overt) existence in the industry on the basis of a specific marker ${ }^{1}$. Instead, we strive to answer the question regarding whether the observed series of price levels can be compatible with the known model of the strategic interaction of players (may be part of the equilibrium of a game).

On the basis of industry ${ }^{2}$ research, important factors that influence the strategic conduct of the market participants can be enumerated: a duopolistic market with high concentration, homogeneous products, high barriers to entry, capacity constraints for domestic production, inelastic demand, possible IPP ${ }^{3}$ pricing mechanism and major players' full price transparency.

Based on these characteristics, it is possible to restrict the set of adequate models of noncooperative games by the specification of the essential elements of a game model. These specifications include the following: the price should be considered as a main strategic variable for the players, there were no threats of significant entry to the market in the sample period, and production capacities should be treated as exogenous parameters in the game period. Through these restrictions, one can isolate a single period game as a non-zero-sum, simultaneous moves finite game in pure action spaces. This set of assumptions leads to a choice of a standard Bertrand model as a building block of certain one-shot games; this is enriched with additional elements to eliminate equilibrium in marginal costs as the sole solution. Models based on the well-known Edgeworth model (1925) would be particularly well-suited in this instance. Edgeworth's model modifications have led to various models, for example, those by Levitan and Shubik (1972), Kreps and Scheinkman (1983), Osborne and Pitchik (1986), Deneckere and Kovenock (1992). Because those models are essentially static, one can consider a proper dynamic specification. In this case, a highly popular Maskin and Tirole (1988) model and a supergame approach to oligopolistic competition could be considered. As a reference work in that topic, one can point to Tirole (1998) and Vives (2001). For our empirical research, the works of Brock and Scheinkman (1985), Lambson (1987), Green and Porter (1984), Rotemberg and Saloner (1986), Dudey (1992), Lu and Wright (2010) could be inspirational because of the choice of price as a strategic variable and because of the imposed capacity constraints in certain games. However, analyzing the abovementioned models, we can conclude that their structures do not explain

\footnotetext{
${ }^{1}$ Refer to: Harringtopn (2006, 2008) or Aberantes-Metz (2011, 2013), Abrantes-Metz and Bajari (2012).

${ }^{2}$ Details of that study will be published in an another paper.

${ }^{3}$ Import Parity Pricing.
} 
the very important market's phenomenon, i.e., IPP pricing mechanism. In our view, such a mechanism leads to a concept of a reference point in strategic interactions that could be described as a focal point or ceiling point. There is substantial empirical evidence of the use of focal point prices by firms. Scherer (1980) found price lining is widespread at the retail level in the US. Using data from the US-credit card market during the 1980s, Knittel and Stango (2003) show that nonbinding price ceilings, which serve as external focal points, increase the probability that firms engage in tacit collusion. In Faber, Janssen (2011), they investigated the focal point effects of oil companies that suggest petrol and diesel prices to their retailers. We wanted to utilize the concept then but formulate the question slightly differently: what were the strategic implications of IPP treated as the "focal price" for player's daily actions (price levels)? We then decided to construct a game theory model of pricing behavior that is suitable for the industry's parameters ${ }^{4}$. The main conclusions from our theoretical model are the following:

- it is strategically possible to use the same (or very close) price levels by both players in daily interactions; therefore, regarding the parallel pricing phenomenon, we can state,

- the common price level for both players should be very close to the IPP price level (or a proxy of it), if we assume the ability of players to properly calculate it on the basis of commonly known factors.

Thus, the primary purpose of this article concerns the empirical verification of the first of the above implications. We want to determine whether the observable data reflects parallel pricing strategic behavior in a market and, as an implication, if the rational conduct of the players is coherent with the equilibrium strategies of a game theory model. Few studies of broad price movements and dependencies in the Polish refining sector in general (Bejger and Bruzda, 2002; Miłobędzki, 2008; Leszkiewicz-Kędzior, 2012) exist; in addition, no such studies (to our knowledge) are devoted to analyzing the pricing behavior of both players in parallel, focused on the strategic interactions among them.

The methodological construction of the research first contains the basic statistical measures of the empirical distributions of prices used; finally, it examines the cointegration between the prices of players and the existence of the long-term and short-term relations (if any) for the two series. To investigate the construction, the ARDL - bound testing approach was used because it is fairly universal and insensitive to the misspecification of integration order. The remainder of this paper is structured as follows. Section 2 briefly

${ }^{4}$ Bejger (2015), forthcoming. 
outlines the data. Section 3 reviews the estimation techniques and contains the empirical analysis. Section 4 presents the study's conclusions.

\section{Data Description}

The main data set covers wholesale (unregular) daily prices on PKN PB95, PKN ON, LOTOS PB95 and LOTOS ON in PLN for cubic meters and the 01.01.2004-31.12.2013 sample period. These four time series have been obtained from official websites of the players ${ }^{5}$. We decided to conduct research on two slightly different data sets from the basic sample; we examined "raw" series (of different lengths) to reveal their individual properties. Next, we synchronized these data sets to study cointegration. In the raw data analysis, we did not subtract the excise tax and fuel duty because the reactions of price levels to the changes in these duties could contain information regarding the strategic behavior of players. For the purpose of synchronization of the observations, we used the dates of observations of PKN's gasoline price as reference. Missing daily observations of LOTOS were replaced by simple extrapolation between the values observed immediately before and after; therefore, both final series have 2281 observations. Such transformation of LOTOS' data did not harm the statistical properties of original series substantially (integration order unchanged, descriptive statistics that are closer to PKN in values). Additionally, we simplified the names of the synchronized series to LOTOSPB and PKNPB to use them as variable names.

Figure 1 shows raw data. There are obvious similarities in the time evolution of the prices of the same type of fuel in both players and in the differences in the price processes of different fuels.

As a preliminary examination, the basic descriptive statistics of the (raw) series were calculated. Table 1 contains the results of this step for the individual series (in levels) ${ }^{6}$. From the results, one can observe the similarities of moments for the same type of fuels and the strong rejection of the normality of empirical distributions in all cases.

\footnotetext{
${ }^{5} \mathrm{http}: / /$ www.orlen.pl/PL/DlaBiznesu/HurtoweCenyPaliw; http://www.lotos.pl/144/dla_biznesu/hurtowe_ceny_paliw.

${ }^{6}$ As we can observe, the series are of different length. For statistical or econometric research, this difference is an obvious disadvantage; however, we rely strongly on daily observations such as those that could reveal strategic patterns in player's behavior.
} 

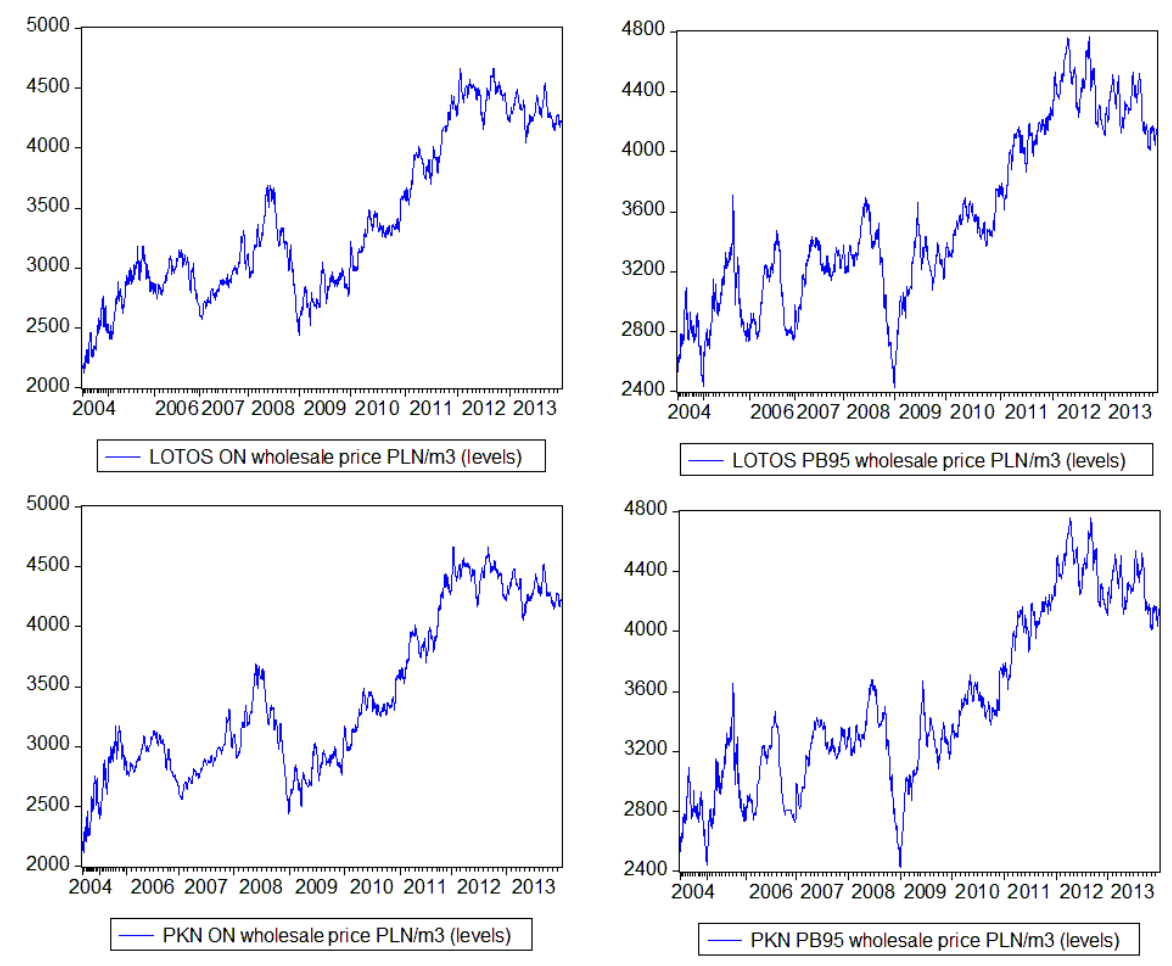

Figure 1. Time series of prices (wholesale, fuels)

Table 1. Descriptive statistics

\begin{tabular}{ccccc}
\hline & PKN PB95 & PKN ON & LOTOS PB95 & LOTOS ON \\
\hline Mean $^{*}$ & 3521.64 & 3400.70 & 3530.19 & 3375.92 \\
Median $^{*}$ & 3374.00 & 3184.00 & 3381.00 & 3153.00 \\
Maximum $^{*}$ & 4757.00 & 4663.00 & 4768.00 & 4667.00 \\
Minimum* $^{*}$ & 2425.00 & 2117.00 & 2428.00 & 2121.00 \\
Std. Dev. $^{*}$ & 573.84 & 657.40 & 572.05 & 664.37 \\
Coef. Of var. & $16.29 \%$ & $19.33 \%$ & $16.20 \%$ & $19.68 \%$ \\
Skewness & 0.36 & 0.45 & 0.35 & 0.45 \\
Kurtosis & 1.98 & 1.81 & 1.97 & 1.87 \\
Jarque-Bera & 149.24 & 194.44 & 149.95 & 204.37 \\
p-value & 0.00 & 0.00 & 0.00 & 0.00 \\
Number of Obs. & 2281 & 2094 & 2343 & 2343 \\
\hline
\end{tabular}

Note: * - values in PLN. 


\section{Estimation Techniques and Empirical Analysis}

As stated in the introduction, the main objective for this research was an empirical verification of the pricing schema that was implied by the theoretical model of strategic interaction (the focal price game), parallel pricing strategic behavior.

At first, the model has to specify what statistical and econometric measures can be used to verify such pricing. If one understands movements of prices as parallel pricing, Buccirossi (2006) stated, on the basis of a simple game, that: "concise representation of the degree of price parallelism is provided by the correlation between prices"7. A testable proposition (partly adequate to our case) is: "If that the market is perturbed only by shocks on costs, then: if shocks are perfectly common, the correlation between prices equals 1 in both the competitive and the collusive equilibrium" ${ }^{\prime 8}$. Of course, such an ascertainment is consistent with intuition of course; however, in our opinion, simple correlation is not a sufficient tool for time series of very complex structure. We can begin from this point; however, we test other measures of similarity of series, as well. However, first, we want to determine whether the parallel movement could be observed not only in the common- comovement of the levels. Parallelism could mean similar patterns in the empirical distributions of price changes and price grids, for example. We want to research that possibilities at first and move to the examination of co-movements next. To limit the size of the analysis, and for data availability, we focused solely on gasoline prices. We began with raw data (daily observations not paired) to obtain as much information as possible.

\subsection{Statistical Analysis of the Gasoline Price Changes}

To check the movements of the price changes more closely, we calculated the positive and negative average changes of values (in PLN) and their relation to the price level. The results are shown in Table 2.

At the beginning of the sample period (2004 and 2005), a higher relative average change can be noticed, which could be connected to higher grid price levels in that period for LOTOS (Figure 2).

\footnotetext{
${ }^{7}$ Buccirossi (2006), p. 92.

${ }^{8}$ Proposition 3, Buccirossi (2006), p. 94.
} 
Table 2. Average positive and negative changes of prices by years

\begin{tabular}{cccccc}
\hline \multicolumn{2}{c}{ LOTOS PB95 } & \multicolumn{3}{c}{ PKN PB95 } \\
\hline \multirow{2}{*}{ year } & avg. change & $\begin{array}{c}\text { avg. change as } \\
\% \text { of price }\end{array}$ & avg. change & $\begin{array}{c}\text { avg. change as \% } \\
\text { of price }\end{array}$ & $\begin{array}{c}\text { abs. difference } \\
\text { of \% change }\end{array}$ \\
\hline \multirow{2}{*}{2004} & 37.95 & $1.374 \%$ & 39.40 & $1.426 \%$ & $0.052 \%$ \\
& -37.55 & $-1.348 \%$ & -41.53 & $-1.488 \%$ & $0.140 \%$ \\
2005 & 38.08 & $1.280 \%$ & 46.83 & $1.575 \%$ & $0.296 \%$ \\
& -40.60 & $-1.315 \%$ & -55.71 & $-1.801 \%$ & $0.486 \%$ \\
2006 & 22.18 & $0.729 \%$ & 12.04 & $0.397 \%$ & $\mathbf{0 . 3 3 2 \%}$ \\
& -21.79 & $-0.712 \%$ & -14.32 & $-0.472 \%$ & $\mathbf{0 . 2 4 1 \%}$ \\
2007 & 20.47 & $0.652 \%$ & 13.47 & $0.432 \%$ & $\mathbf{0 . 2 2 0 \%}$ \\
& -15.05 & $-0.466 \%$ & -10.37 & $-0.322 \%$ & $\mathbf{0 . 1 4 4 \%}$ \\
2008 & 18.42 & $0.552 \%$ & 13.59 & $0.410 \%$ & $\mathbf{0 . 1 4 3 \%}$ \\
& -22.58 & $-0.709 \%$ & -18.69 & $-0.594 \%$ & $\mathbf{0 . 1 1 5 \%}$ \\
2009 & 25.47 & $0.821 \%$ & 23.80 & $0.771 \%$ & $0.049 \%$ \\
& -20.60 & $-0.632 \%$ & -15.02 & $-0.461 \%$ & $\mathbf{0 . 1 7 0 \%}$ \\
2010 & 18.21 & $0.519 \%$ & 17.71 & $0.505 \%$ & $0.015 \%$ \\
& -14.90 & $-0.422 \%$ & -12.83 & $-0.363 \%$ & $0.059 \%$ \\
2011 & 20.39 & $0.508 \%$ & 19.43 & $0.484 \%$ & $0.024 \%$ \\
& -20.40 & $-0.505 \%$ & -19.35 & $-0.479 \%$ & $0.026 \%$ \\
2012 & 17.05 & $0.383 \%$ & 16.33 & $0.368 \%$ & $0.015 \%$ \\
& -22.98 & $-0.515 \%$ & -21.59 & $-0.485 \%$ & $0.031 \%$ \\
2013 & 19.99 & $0.468 \%$ & 19.08 & $0.447 \%$ & $0.021 \%$ \\
& -18.88 & $-0.439 \%$ & -17.53 & $-0.408 \%$ & $0.031 \%$ \\
\hline
\end{tabular}

Note: Bolded numbers mean the rejection of $\mathrm{H} 0$ regarding the equality of a mean positive or negative change of prices between LOTOS and PKN in a particular year.

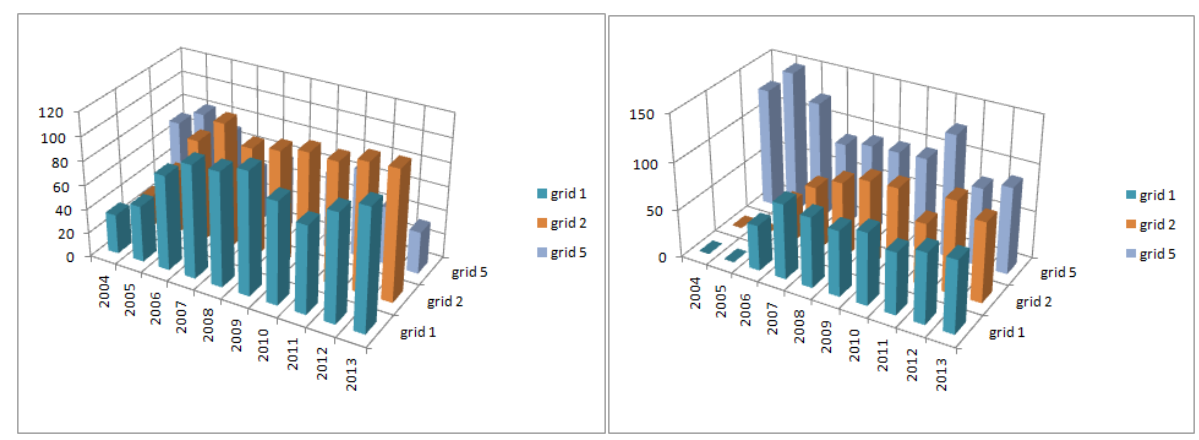

Figure 2. Empirical distribution of price grids - PKN PB95 (left panel) and LOTOS PB95 (right panel)

PKN's grid was more evenly distributed; however, grid 5 was dominant in 2004 and 2005, as well. In accordance with Table 2, 2006-2008 were very 
different than the remainder of the sample because the average changes (of both signs) decreased but became significantly different for both players. Those changes signal disturbances in the behavior of players in that period. As can be observed, the beginning of this change corresponds to LOTOS' introduction of values other than 5 PLN of the price grid and the synchronization of the announcement of prices. From 2009 to the end of the sample average price, the changes became statistically equal; however, we can subjectively (not in the statistical sense) observe that considering relative changes, upward movements were closer. The last interesting analysis of raw data is contained in Table 3.

Table 3. Daily distributions of price changes

\begin{tabular}{|c|c|c|c|c|c|c|c|c|c|c|}
\hline & & & & & \multicolumn{3}{|c|}{ LOTOS PB95 } & \multicolumn{3}{|c|}{ PKN PB95 } \\
\hline & $\begin{array}{c}\text { LOTOS } \\
\text { PB95 }\end{array}$ & $\begin{array}{l}\text { PKN } \\
\text { PB95 }\end{array}$ & $\begin{array}{l}\text { LOTOS } \\
\text { PB95 } \\
\text { change }\end{array}$ & $\begin{array}{c}\text { PKN } \\
\text { PB95 } \\
\text { change }\end{array}$ & up & down & $\begin{array}{c}\text { no } \\
\text { change }\end{array}$ & up & down & $\begin{array}{c}\text { no } \\
\text { change }\end{array}$ \\
\hline Mon & 8 & 3 & $0.3 \%$ & $0.1 \%$ & $0.3 \%$ & $0.2 \%$ & $0.1 \%$ & $0.2 \%$ & $0.0 \%$ & $0.5 \%$ \\
\hline Tue & 432 & 441 & $18.6 \%$ & $19.6 \%$ & $19.1 \%$ & $18.0 \%$ & $17.8 \%$ & $20.1 \%$ & $19.1 \%$ & $16.7 \%$ \\
\hline Wen & 439 & 446 & $18.2 \%$ & $19.5 \%$ & $17.8 \%$ & $18.7 \%$ & $217 \%$ & $17.2 \%$ & $220 \%$ & $19.8 \%$ \\
\hline Thur & 457 & 469 & $19.9 \%$ & $20.6 \%$ & $18.0 \%$ & $21.9 \%$ & $17.2 \%$ & $21.0 \%$ & $20.2 \%$ & $19.3 \%$ \\
\hline Frid & 461 & 456 & $19.8 \%$ & $19.8 \%$ & $20.7 \%$ & $18.9 \%$ & $18.9 \%$ & $20.4 \%$ & $19.2 \%$ & $22.4 \%$ \\
\hline Sat & 476 & 462 & $20.7 \%$ & $20.3 \%$ & $21.6 \%$ & $19.8 \%$ & $18.1 \%$ & $21.0 \%$ & $19.5 \%$ & $19.8 \%$ \\
\hline Sun & 70 & 4 & $2.5 \%$ & $0.0 \%$ & $2.5 \%$ & $2.6 \%$ & $5.6 \%$ & $0.1 \%$ & $0.0 \%$ & $1.6 \%$ \\
\hline
\end{tabular}

Note: Columns up, down, no change contain contribution of daily up, down, no change price movements in whole number of movements of a given type. Highest values bolded.

Table 3 refers to the daily distributions of price movements of both players; there are certain differences. However, after checking pairs of empirical distributions of the same type (i.e., LOTOS up - PKN up) using the Kolmogorov-Smirnov test, we could not reject the hypothesis of the equality of cumulative distributions. Therefore, the days of movements of prices are largely the same.

\subsection{Cointegration Analysis}

\subsubsection{ARDL - Bounds Testing Procedure}

With that test, we want to move to the next step of our research, testing the common movements of both price series.

Preliminarily, we checked the correlation coefficient for both series. As we expected, correlations were very strong, with a magnitude of 0.99 in the entire sample and not below 0.97 in the sub-samples that encompass each year. However, for the possible cointegrated series, we need a more precise 
evaluation of the co-movement. We were interested in determining whether a cointegration exists between the prices of players, and what type of longrun and short-run relations (if any) exist for the two series. To study these relations, we decided to use the ARDL-bound testing approach. The ARDL modeling approach was originally introduced by Pesaran and Shin (1999) and extended by Pesaran et al. (2001). The ARDL cointegration approach has numerous advantages over conventional cointegration testing. The approach yields consistent estimates of the long-run coefficients that are asymptotically normal irrespective of whether the underlying regressors are $\mathrm{I}(1)$ or $\mathrm{I}(0)$. The approach involves a single-equation set-up, which is simple to implement and interpret; different lag-lengths can be assigned to model variables. In accordance with Pesaran, Shin (1999), we consider a general $\operatorname{ARDL}(\mathrm{p} ; \mathrm{q})$ model:

$$
\begin{aligned}
& y_{t}=\alpha_{0}+\alpha_{t} t+\sum_{i=1}^{p} \Phi_{i} y_{t-i}+\beta^{\prime} \boldsymbol{x}_{t}+\sum_{j=0}^{q} \beta_{J}^{*} \Delta^{\prime} \boldsymbol{x}_{t-\jmath}+u_{t}, \\
& \Delta \boldsymbol{x}_{t}=\boldsymbol{P}_{1} \Delta \boldsymbol{x}_{t-1}+\boldsymbol{P}_{2} \Delta \boldsymbol{x}_{t-2}+\cdots+\boldsymbol{P}_{s} \Delta \boldsymbol{x}_{t-s}+\varepsilon_{t} .
\end{aligned}
$$

The scalar disturbance, $\mathrm{u}_{\mathrm{t}}$ in the model (1) is $\operatorname{iid}\left(0 ; \sigma_{u}^{2}\right)$.

We do not want to impose any integration assumption .

The ARDL model used in this study is a version of eq. (1), which could be called an unrestricted ECM or, as in Pesaran et al. (2001), a conditional ECM. The model is as follows:

$$
\begin{aligned}
\operatorname{LOTOSPB}_{\mathrm{t}}= & \alpha_{0}+\sum_{i=1}^{p} \Phi_{i} \Delta \mathrm{LOTOSPB}_{t-i}+\sum_{j=0}^{q} \beta_{j} \Delta P K N P B_{t-j}+ \\
& \theta_{0} \text { LOTOSPB }_{t-1}+\theta_{1} \text { PKNPB }_{t-1}+\varepsilon_{t}
\end{aligned}
$$

where we assume the LOTOS price as "dependent", in accordance with Miłobędzki (2008), when he concluded that PKN is a "price leader" in the industry.

\subsubsection{Empirical Analysis}

First, a test for order of integration was conducted. Although the bounds test for cointegration allows variables to be a mixture of $\mathrm{I}(1)$ and $\mathrm{I}(0)$, it is important to conduct stationarity tests to ensure that the variables are not all $\mathrm{I}(0)$ and not $\mathrm{I}(2)$. The results reported in Table 4 confirm that all series have one unit root, i.e. all are I(1).

To exclude the possibility of distinct leader-follower strategic behavior in the entire sample, we next tested for causality between the variables. Us-

\footnotetext{
${ }^{9}$ The order of integration was preliminary tested (Table 4); however, those were usual tests (ADF and KPSS). We did not test the order of integration more thoroughly (in the presence of breaks in intercept and/or trend, for example).
} 
ing the Toda-Yamamoto procedure (Toda and Yamamoto, 1995), the Granger causality in both directions between the price series was found. Table 5 contains the final Wald test of the Granger non-causality for VAR with 13 lags (optimal lag length selected for VAR was $12+1$ lag to explain I(1) in each variable, treated here as exogenous).

Table 4. ADF Test for unit root

\begin{tabular}{|c|c|c|c|c|c|c|}
\hline \multicolumn{3}{|c|}{ Level } & \multicolumn{4}{|c|}{ 1st difference } \\
\hline Series & $\begin{array}{l}\text { ADF test } \\
\text { statistics }\end{array}$ & $p$-value* & Lag & $\begin{array}{l}\text { ADF test } \\
\text { statistics }\end{array}$ & p-value* & Lag \\
\hline PKN PB95 & 0.484 & 0.819 & 2 & -21.875 & 0.000 & 2 \\
\hline PKN ON & 0.845 & 0.893 & 2 & -24.608 & 0.000 & 1 \\
\hline LOTOS PB95 & 0.509 & 0.825 & 2 & -20.218 & 0.000 & 3 \\
\hline LOTOS ON & 0.887 & 0.899 & 2 & -22.859 & 0.000 & 2 \\
\hline
\end{tabular}

Note: ADF Test for H0: series has a unit root. Test's critical value at the $1 \%$ level: -2.56607 . We conducted the KPSS test for all series with the same results (all series I(1)). MacKinnon (1996) one-sided p-values.

Table 5. Wald tests for Granger causality

\begin{tabular}{|c|c|c|c|}
\hline \multicolumn{4}{|c|}{ Dependent variable: LOTOSPB } \\
\hline Excluded & Chi-sq & $\mathrm{df}$ & $\mathrm{p}$-value \\
\hline PKNPB & 284.433 & 12 & 0.000 \\
\hline All & 284.433 & 12 & 0.000 \\
\hline \multicolumn{4}{|c|}{ Dependent variable: PKNPB } \\
\hline Excluded & Chi-sq & $\mathrm{df}$ & p-value \\
\hline LOTOSPB & 105.109 & 12 & 0.000 \\
\hline All & 105.109 & 12 & 0.000 \\
\hline
\end{tabular}

The null hypothesis of no causality in both directions must be rejected. Regarding the specifications of the model, the lag structure of (3) has been defined. The ardlbound: An Eviews add-in by Tarverdi M. Yashar (2014) was utilized here. The parameters of the ARDL $(1,2)$ model were subsequently estimated. The residuals were tested for a serial correlation next because the key assumption in the ARDL / Bounds Testing methodology is that the errors of equation (3) must be serially independent. Table 6 summarizes the results of those steps.

The estimation results for the $\operatorname{ARDL}(1,2)$ specification of choice are satisfactory; all coefficients (except one) are statistically significant (at the 0.05 level), and the residuals are serially independent. Having the parameters' estimates, we next apply a bounds F-test to Eq (3). The long run relation between LOTOSPB and PKNPB series was sought. As usually occurs in 
cointegration testing, the absence of a long-run equilibrium relation between the variables was tested for. The hypothesis structure was as follows:

$$
\begin{aligned}
& \mathrm{H}_{0}: \theta_{0}=\theta_{1}=0, \\
& \mathrm{H}_{1}: \theta_{0} \neq \theta_{1} .
\end{aligned}
$$

\begin{tabular}{|c|c|c|c|c|}
\hline ARDL Model & AIC & $\mathrm{SC}$ & & \\
\hline ARDL(1,1) & 9.2751 & 9.2852 & & \\
\hline $\operatorname{ARDL}(1,2)$ & 9.2721 & 9.2847 & & \\
\hline $\operatorname{ARDL}(1,3)$ & 9.2732 & 9.2883 & & \\
\hline Variable & Coefficient & Std. Error & t-Statistic & $p$-value \\
\hline $\mathrm{C}$ & 6.7113 & 3.2528 & 2.0632 & 0.0392 \\
\hline D(LOTOSPB $(-1))$ & -0.0374 & 0.0408 & -0.9160 & 0.3598 \\
\hline $\mathrm{D}(\mathrm{PKNPB}(-1))$ & 0.3875 & 0.0408 & 9.4960 & 0 \\
\hline $\mathrm{D}(\mathrm{PKNPB}(-2))$ & 0.0675 & 0.0216 & 3.1240 & 0.0018 \\
\hline LOTOSPB(-1) & -0.2645 & 0.0438 & -6.0310 & 0 \\
\hline PKNPB(-1) & 0.2629 & 0.0438 & 5.9938 & 0 \\
\hline \multicolumn{5}{|c|}{ Breusch-Godfrey Serial Correlation LM Test: Durbin-Watson statistic } \\
\hline F-statistic & 0.7081 & \multirow{2}{*}{\multicolumn{2}{|c|}{$\begin{array}{c}\text { Prob. F(3,2269) } \\
\text { Prob. Chi-Square(3) }\end{array}$}} & 0.5471 \\
\hline Obs*R-squared & 2.1309 & & & 0.5457 \\
\hline Durbin-Watson stat & 1.9988 & & & \\
\hline
\end{tabular}

Table 6. ARDL $(\mathrm{p}, \mathrm{q})$ model selection and estimation

Note: AIC and SC information criteria for the ARDL preferred structure are in bold. Variables $\mathrm{D}(*)$ are the first differences of the series of levels.

A rejection of $\mathrm{H}_{0}$ implies that there is a long-run relation between series. The F-statistics in the form presented in Pesaran et al. (2001), p. 297, equation (21) was used. Because this statistic has non-standard distributions, in accordance with the so-called bounds procedure proposed by Pesaran et al. (2001), we tested $\mathrm{H}_{0}$ within the conditional ECM (3). The researchers provided bounds on the critical values for the asymptotic distribution of the Fstatistic for various specifications of ECM for sizes 0.100, 0.050, 0.025 and 0.010 of the test. The lower bound values assume that the forcing variables are purely $\mathrm{I}(0)$, and the upper bound values assume that variables are purely I(1). If the computed F-statistics fall outside the critical value bounds, a conclusive decision results without needing to know the cointegration rank $r$ of the variables. However, if the Wald or F-statistic falls within these bounds, the inference would be inconclusive. In such circumstances, knowledge of the cointegration rank $r$ of the forcing variables is required to proceed further ${ }^{10}$. Additionally, a bounds t-test of the $\theta_{0}$ estimated value was performed:

${ }^{10}$ Pesaran et al (2001), p. 299. 


$$
\begin{aligned}
& \mathrm{H}_{0}: \theta_{0}=0, \\
& \mathrm{H}_{1} \theta_{0}<0 .
\end{aligned}
$$

Asymptotic critical t-statistic's values for this test are provided by Pesaran et al. (2001, p. 303-304) in a form of similar to the F-statistic's $I(0)-I(1)$ bounds, calculated for various specifications. Inference is similar, either the calculated t-value is smaller than the lower bound, which means stationarity of the data; a t-value higher than I(1) bound supports the hypothesis of a long run relation. Table 7 concludes this examination:

Table 7. Bounds testing

\begin{tabular}{cccc}
\hline test statistic & calculated value & & \\
\hline F-statistic & 19.6814 & & \\
t-statistic & -6.0310 & & 0.01 \\
\hline significance level & 0.1 & 0.05 & $6.84 ; 7.84$ \\
F-stat. bounds & $4.04 ; 4.78$ & $4.94 ; 5.73$ & $-3.43 ;-3.82$ \\
t-stat.bounds & $-2.57 ;-2.91$ & $-2.86 ;-3.22$ & \\
\hline
\end{tabular}

Note: Bound values from Pesaran et al. (2001), p.300, p.303 for unrestricted intercept, no trend specification and $\mathrm{k}=1$.

It can be stated that because the value of our F-statistic and t-statistic exceeds the upper bound at the $1 \%$ significance level, there was evidence of a long-run relation between the LOTOSPB and PKNPB. The estimated longrun multiplier between PKNPB and LOTOSPB is $-(0.262933 /-0.264599))=$ 0.9937; therefore, in the long run, an increase of 1 unit in PKNPB will lead to an increase of 0.9937 units in LOTOSPB.

After confirming cointegration, there was a possibility to estimate the longrun relation meaningfully:

$$
\text { LOTOSPB }_{\mathrm{t}}=\alpha_{0}+\alpha_{1} \text { PKNPB }_{t-1}+v_{t},
$$

and use the OLS residuals series from the (4) as an error correction term to estimate the restricted ECM of the form:

$$
\begin{aligned}
\Delta \text { LOTOSPB }_{\mathrm{t}}= & \alpha_{0}+\sum_{i=1}^{p} \Phi_{i} \Delta \mathrm{LOTOSPB}_{t-i}+\sum_{j=0}^{q} \beta_{j} \Delta P K N P B_{t-j}+ \\
& \varphi E C_{t-1}+\varepsilon_{t}
\end{aligned}
$$

where:

$$
E C_{t-1}=\left(L O T O S P B_{t-1}-a_{0}-a_{1} P K N P B_{t-1}\right)
$$

and $a_{0}, a_{1}$ are OLS estimates of parameters in (6).

Table 8 contains estimated values of parameters in (5). 
Table 8. Estimation of parameters of restricted ECM

\begin{tabular}{ccccc}
\hline Variable & Coefficient & Std. Error & t-Statistic & p-value \\
\hline C & 0.3822 & 0.5224 & 0.7316 & 0.4644 \\
D(LOTOSPB $(-1))$ & -0.0367 & 0.0408 & -0.8988 & 0.3688 \\
D(PKNPB $(-1))$ & 0.3866 & 0.0408 & 9.4719 & 0.0000 \\
D(PKNPB $(-2))$ & 0.0666 & 0.0216 & 3.0800 & 0.0021 \\
EC $(-1)$ & -0.2649 & 0.0438 & -6.0368 & 0.0000 \\
\hline
\end{tabular}

Note: Variables $\mathrm{D}(*)$ are the first differences of the series in levels.

It can be observed that the estimated coefficient of the error-correction term, ECt-1, is negative, as expected, and significant. The absolute value of this coefficient implies that approximately $27 \%$ of any disequilibrium between the LOTOSPB price level and the PKNPB price level is corrected within one day.

\subsection{Preliminary Analysis of Leader-follower Behavior in Subsamples}

The last problem, which was preliminarily examined, was the leaderfollower behavior of a more complicated nature (as replications of certain patterns in price changes and price announcements), which was exhibited in the sub-samples. To begin, the sub-samples were examined in the most intuitive manner, consistent with the assumed pricing mechanism, i.e., by testing the differences between the same day prices of both players, the current price of one of the players and the lagged price of the other. Figure 3 provides the possibility to visually inspect various series of differences of prices of the players:
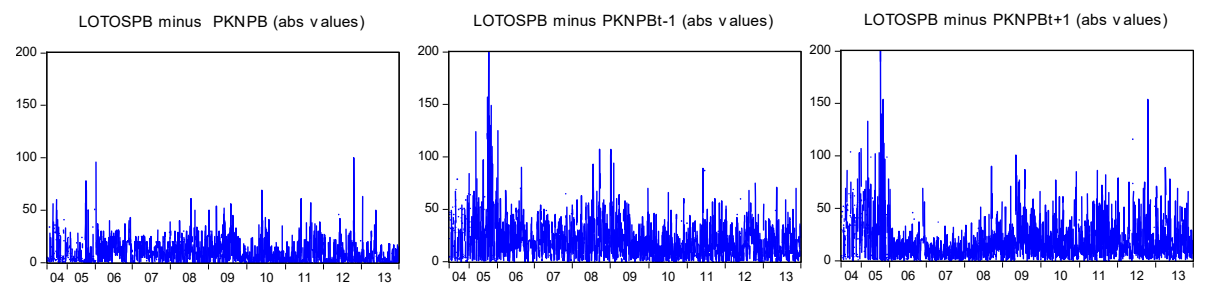

Figure 3. Absolute values of differences between levels of prices of players and the entire sample

The differences of the same day prices appear to have the smallest mean and variance; however, an interesting period (it covers nearly precisely all observations of 2007) in the series of differences of the PKNPB and lagged 1-day 
Table 9. Price's differences analysis

\begin{tabular}{|c|c|c|c|c|c|}
\hline & \multicolumn{3}{|c|}{ Descriptive statistics - whole sample } & \multicolumn{2}{|c|}{$\begin{array}{c}\text { Descriptive statistics - year } \\
2007 \text { subsample }\end{array}$} \\
\hline & $\mathrm{S}_{1}=\mathrm{y}_{\mathrm{t}}-\mathrm{x}_{\mathrm{t}}$ & $\mathrm{S}_{2}=\mathrm{y}_{\mathrm{t}}-\mathrm{x}_{\mathrm{t}-1}$ & $\mathrm{~S}_{3}=\mathrm{x}_{\mathrm{t}}-\mathrm{y}_{\mathrm{t}-1}$ & $S_{1}=y_{t}-x_{t}$ & $\mathrm{~S}_{3}=\mathrm{xt}_{\mathrm{t}}-\mathrm{yt}_{\mathrm{t}-1}$ \\
\hline Mean & 9.749 & 20.873 & 19.386 & 11.530 & 8.724 \\
\hline Median & 6 & 16 & 14 & 10 & 7 \\
\hline Std. Dev. & 10.755 & 19.391 & 19.853 & 7.980 & 6.814 \\
\hline Skewness & 1.992 & 2.529 & 2.802 & 0.341 & 1.077 \\
\hline Kurtosis & 10.060 & 17.332 & 18.119 & 2.348 & 4.251 \\
\hline \multicolumn{6}{|c|}{ Test - equality of means $E\left(S_{1}\right)=E\left(S_{2}\right)$} \\
\hline & & test stat value & $p$-value & test stat value & $\mathrm{p}$-value \\
\hline & & -23.9695 & 0.0000 & & \\
\hline Ano & E-test & 574.5346 & 0.0000 & & \\
\hline \multicolumn{6}{|c|}{ Test - equality of means $E\left(S_{1}\right)=E\left(S_{3}\right)$} \\
\hline & & -20.4223 & 0.0000 & 4.2020 & 0.0000 \\
\hline Ano & E-test & 417.0719 & 0.0000 & 17.6569 & 0.0000 \\
\hline \multicolumn{6}{|c|}{ Test - equality of medians $\mathrm{Me}\left(\mathrm{S}_{1}\right)=\mathrm{Me}\left(\mathrm{S}_{2}\right)$} \\
\hline Wilcoxon/M & -Whitney (tie- & 24.3783 & 0.0000 & & \\
\hline Adj. Me & hi-square & 441.7884 & 0.0000 & & \\
\hline van de & laerden & 613.5586 & 0.0000 & & \\
\hline \multicolumn{6}{|c|}{ Test - equality of medians $\mathrm{Me}\left(\mathrm{S}_{1}\right)=\mathrm{Me}\left(\mathrm{S}_{3}\right)$} \\
\hline $\begin{array}{r}\text { Wilcoxon/ } \\
(\mathrm{t}\end{array}$ & $\begin{array}{l}\text { nn-Whitney } \\
\text { dj.) }\end{array}$ & 21.4293 & 0.0000 & 3.8747 & 0.0001 \\
\hline Adj. Me & hi-square & 346.6815 & 0.0000 & 18.6559 & 0.0000 \\
\hline van de & laerden & 502.5227 & 0.0000 & 11.8360 & 0.0006 \\
\hline \multicolumn{6}{|c|}{ Test - equality of variances $\operatorname{var}\left(\mathrm{S}_{1}\right)=\operatorname{var}\left(\mathrm{S}_{2}\right)$} \\
\hline & & 3.4100 & 0.0000 & & \\
\hline & & 808.2732 & 0.0000 & & \\
\hline Brow & rsythe & 201.9853 & 0.0000 & & \\
\hline \multicolumn{6}{|c|}{ Test - equality of variances $\operatorname{var}\left(\mathrm{S}_{1}\right)=\operatorname{var}\left(\mathrm{S}_{3}\right)$} \\
\hline & & 3.2498 & 0.0000 & 1.371368 & 0.0135 \\
\hline & & 749.3125 & 0.0000 & 6.096009 & 0.0135 \\
\hline Brow & rsythe & 282.6512 & 0.0000 & 9.518529 & 0.0021 \\
\hline
\end{tabular}

Note: Series $\mathrm{x}$ - PKNPB in levels, series $\mathrm{y}$ - LOTOSPB in levels. All the series in PLN/m3.

price of LOTOS (rightmost panel) ${ }^{11}$ can be observed. Descriptive statistics and various test statistics are reported in Table 9. These statistics confirm that the measures of the average level and dispersion were significantly different in a case of three series, $S_{1}, S_{2}$ and $S_{3}$, and that the smallest values of

\footnotetext{
${ }^{11}$ To ensure coherent interpretation, we use differences LOTOS - PKN in every case; however, for absolute values, $\mathrm{x}-\mathrm{y}_{\mathrm{t}+1}=\mathrm{y}-\mathrm{xt}_{\mathrm{t}-1}$
}

Dynamic Econometric Models 15 (2015) 111-128 
the average and dispersion measures can be observed in a case of differences between the same day prices in an entire sample. This observance excludes the subsample from 2007, when the smallest values of those measures for the difference between LOTOS' day $t$ price and PKN's day $t+1$ price were noted.

These results lead to the conclusion that, if the research is restricted to IPP pricing based on previous day fundamentals, the players will, in fact, choose levels of prices in a parallel mode; this excludes 2007, when LOTOS appeared to be the price leader ${ }^{12}$.

\section{Conclusions}

To inspect the parallel pricing policy, certain descriptive statistics for the raw price series (not paired) were calculated to evaluate how consistent the pricing policies were. This study found that for the entire sample, an average positive and negative value of prices change were statistically equal (on standard 0.05 significance level); however, the mean changes between players were significantly different. Analysis of the yearly subsamples revealed that the years 2006-2008 were highly different than the remainder of the sample because the average changes (of both signs) decreased but became significantly different for the both players. That finding signals certain disturbances in the behavior of players in that period. The beginning of this change corresponded to LOTOS' introduction of other than 5 PLN values of the price grid and the synchronization of the price announcement. From 2009 to the end of the sample, the average price changes became statistically equal. Analyzing the empirical distributions of price grids and the absolute values of price changes, other differences in pricing policies were detected. However, an examination of the empirical distributions of daily price movements has confirmed that the daily price changes policy of both players was not significantly different over the entire sample period. Next, the casual dependencies and the cointegration of gasoline prices was examined. On the basis of the estimated ARDL $(1,2)$ model, the bound testing procedure of cointegration testing was used. F-test and t-test results have confirmed the existence of a long-run relation between the wholesale prices of gasoline at the $1 \%$ significance level. The estimated long-run multiplier between PKNPB and LOTOSPB was 0.9937; therefore, in the long run, an increase

${ }^{12}$ We have checked the medians and means equality hypothesis in all pairs of the three series of differences for all the year's subsamples and have not confirmed the phenomenon of 2007 in the remaining years. 
of 1 PLN of PKNPB will lead to an increase of 0.9937 PLN in LOTOSPB. The estimation of the regular ECM model provided information regarding the short-run adjustments of prices. The absolute value of the estimated coefficient of the error-correction term implies that approximately $27 \%$ of any disequilibrium between the LOTOSPB price level and the PKNPB price level was corrected within one day. Finally, the simple test of the leaderfollower pricing behavior over the subsamples was performed. To check that test in a manner consistent with the assumed pricing mechanism, the differences between the same day prices of both players, the current price of one of the players and the lagged price of the other were examined.

Overall, this study finds that, if we restricted our research to described pricing mechanism (IPP pricing based on previous day fundamentals) players really chose the levels of price in a parallel mode, with the exclusion of year 2007 when LOTOS appeared to be the price leader.

In terms of the assessment of the players' strategic behavior, this study confirmed that the publically observable pricing conduct of the players in the Polish wholesale fuel market could be consistent with an equilibrium of an assumed game theory model. This finding, in turn, implies that the players' observed behavior was coherent with the assumed competition model and did not exhibit disturbances (unreasonable conduct), which could reflect competition's distortions. However, it should be emphasized that for a decisive "screening" of conclusions based on the model, the test of the second behavioral implication of the theoretical model, i.e., the focal role of the IPP price, must be examined. This test and examination will be a subject of the subsequent research.

\section{References}

Abrantes-Metz, R. (2011), Design and Implementation of Screens and Their Use by Defendants, Antitrust Chronicle, Competition Policy International, 9, 2-11.

Abrantes-Metz, R., Bajari, P. (2012), Screens for Conspiracies and their Multiple Applications, Antitrust Magazine, 24(1), 23-35.

Bejger, S. (2015), Theoretical model of pricing behavior on the Polish wholesale fuel market, Univeristy of Szczecin, forthcoming.

Bejger, S., Bruzda, J. (2002), Identification of market power using test for asymmetric pricing - an example of Polish petrochemical industry, Dynamic Econometric Models, 5, $135-146$.

Brock, W. A., Scheinkman, J. A. (1985), Price Setting Supergames with Capacity Constraints, The Review of Economic Studies, 52, 371-382, DOI: http://dx.doi.org/10.2307/2297659.

Buccirossi, P. (2006), Does Parallel Behavior Provide Some Evidence of Collusion? Review of Law and Economics, 2:1, 86-102, DOI: http://dx.doi.org/10.2202/1555-5879.1027. 
Deneckere, R. J., Kovenock, D. (1992), Price leadership, The Review of Economic Studies, 59, 143-162, DOI: http://dx.doi.org/10.2307/2297930.

Dudey, M. (1992), Dynamic Edgeworth-Bertrand Competition, The Quarterly Journal of Economics, 107(4), 1461-1477, DOI: http://dx.doi.org/10.2307/2118397.

Edgeworth, F. Y. (1925), The pure theory of monopoly, Papers Relating to Political Economy, 1, 111-142.

Faber, R. P., Janssen, M. C. W. (2011), On the Effects of Suggested Prices in Gasoline Markets, Working Paper, CPB Netherlands Bureau for Economic Policy Analysis, Department of Competition and Regulation, DOI: http://dx.doi.org/10.2139/ssrn.1309608.

Green, E., Porter, R. (1984), Non - cooperative collusion under imperfect price information, Econometrica, 52, 87-100.

Harrington, J. E. (2006), Behavioral Screening and the Detection of Cartels, European Competition Law Annual, 234-251.

Harrington, J. E. (2008), Detecting Cartels, in: Buccirossi (ed.) Handbook of Antitrust Economics, The MIT Press.

Knittel, C. R., Stango, V. (2003), Price Ceilings as Focal Points for Tacit Collusion: Evidence from Credit Cards, American Economic Review, 93(5), 1703-1729, DOI: http://dx.doi.org/10.1257/000282803322655509.

Kreps, D., Scheinkman, J. A. (1983), Quantity precommitment and Bertrand competition yield Cournot outcomes, Bell Journal of Economics, 14, 326-337, DOI: $\mathrm{http}: / / \mathrm{dx}$.doi.org/10.2307/3003636.

Lambson, V. E. (1987), Optimal Penal Codes in Price-setting Supergames with Capacity Constraints, The Review of Economic Studies, 54(3), 385-397, DOI: http://dx.doi.org/10.2307/2297565.

Leszkiewicz-Kędzior, K. (2012), Modelling Fuel Prices. An I(1) Analysis; Central European Journal of Economic Modelling and Econometrics, 3, 75-95.

Levitan, R., Shubik, M. (1972), Price duopoly and capacity constraints, International Economic Review, 13, 111-123, DOI: http://dx.doi.org/10.2307/2525908.

Maskin, E., Tirole, J. (1988), A theory of dynamic oligopoly II, Econometrica, 56, 571-599, DOI: http://dx.doi.org/10.2307/1913726.

Miłobędzki, P. (2008), Orlen or Lotos? Which is Setting Prices at the Wholesale Market for Unleaded Petrol in Poland?, Dynamic Econometric Models, 8, 37-43.

Osborne, M., Pitchik, C. (1986), Price competition in a capacity-constrained duopoly, Journal of Economic Theory, 38, 238-260, DOI: $\underline{\text { ttp://dx.doi.org/10.1016/0022-0531(86)90117-1. }}$

Pesaran, H. M., Shin, Y. C., Smith, J. R. (2001), Bounds testing approaches to the analysis of level relationships, Journal of Applied Econometrics, 16, 289-326, DOI: http://dx.doi.org/10.1002/jae.616.

Pesaran, M. H., Shin, Y. (1999), An autoregressive distributed lag modelling approach to cointegration analysis, in S. Strom (ed.), Econometrics and Economic Theory in the 20th Century: The Ragnar Frisch Centennial Symposium, Cambridge University Press, Cambridge, DOI: http://dx.doi.org/10.1017/CCOL521633230.

Rotemberg, J., Saloner, G. (1986), A supergame theoretic model of business cycles and price wars during booms, American Economic Review, 76, 390-407.

Scherer, F. M. (1980), Industrial market structure and performance, 2 ed., Chicago: Rand McNally.

Tarverdi, M. Y. (2014), ardlbound: An Eviews Add-in to perform ARDL bound test based on Pesaran et al. (2001), electronic document provided with program.

Tirole, J. (1998), The Theory of Industrial Organization, The MIT Press, England. 
Toda, H. Y., Yamamoto, T. (1995), Statistical inferences in vector autoregressions with possibly integrated processes, Journal of Econometrics, 66, 225-250, DOI: http://dx.doi.org/10.1016/0304-4076(94)01616-8.

Vives, X. (2001), Oligopoly pricing. Old ideas and new tools, The MIT Press, Cambridge.

Lu, Y., Wright, J. (2010), Tacit collusion with price-matching punishments, International Journal of Industrial Organization, 28, 298-306, DOI: http://dx.doi.org/10.1016/j.ijindorg.2009.10.001.

\section{Test paralelnych zachowań cenowych na hurtowym rynku paliw płynnych w Polsce oparty na podejściu ARDL /bound testing}

Z a r y s t r e ś c i. Artykuł dotyczy badania, czy obserwowane cen paliw płynnych na rynku hurtowym mogą być zgodne $\mathrm{z}$ określonym modelem teoretycznym interakcji strategicznych graczy. Głównym celem badawczym było określanie, czy paralelne zachowania cenowe, implikowane równowagą teoretycznego modelu interakcji strategicznych, mogą być mechanizmem ustalania cen faktycznie obserwowanym na rynku. Aby to stwierdzić wyznaczono statystyki opisowe indywidualnych szeregów czasowych cen dla ustalenia podobieństw. Następnie zbadano współzależność ruchów cenowych graczy wykorzystując podejście ARDL /bound testing. Stwierdzono, że jeśli gracze wykorzystują mechanizm cenowy ceny parytetu importowego (przyjęty w modelu teoretycznym), ich zachowania replikują paralelne zachowanie cenowe, za wyjątkiem roku 2007, w którym LOTOS wydaje się być liderem cenowym.

$\mathrm{S} \nmid \mathrm{ow}$ a k $1 \mathrm{u}$ c z o w e:hurtowy rynek paliw, zachowania paralelne, kointegracja.

Dynamic Econometric Models 15 (2015) 111-128 